\title{
Implementasi Evaluasi Menurut Daniel F. Stufflebeam pada Program PJJ selama Pandemi Covid-19
}

\author{
Fatimatur Rohmah, Abdul Wahid, Silviatul Hasanah \\ Universitas Islam Negeri Walisongo, Semarang, Indonesia \\ vatimeo1980@gmail.com
}

\begin{abstract}
The covid-19 pandemic is hitting Indonesia, but activities in the world of education must keep going. In 2020 the training Center Religious (BDK) Semarang has implemented Distance Training (PJJ) online. PJJ is implemented to provide more space train employees of the Ministry of Religion in Yogyakarta and Central Java.This riset is to determine the context, input, process and product. This research uses are interviews, document review and observation. The result of research in the input aspect in the form of a work system applied alternate, the curriculum is applied in the implementation of PJJ it has adjusted to the provisions of the Ministry of Religion the center, sometimes innovation are made. In the process, the institution has held technical guidance for all employees, so there is no gap in using technology, quantity had more participant, but there are problems with signal difficulties and each participant are given pulses. While the result achieved in the implementation of PJJ all participants passed with an average score of 90 . The Recommendations is implementation of PJJ make prioritized for entered into the work program in the coming year and give more class, as well as institutional facilities for conducting education in a manner online enhanced.
\end{abstract}

Keywords: Evaluation Daniel Stufflebeam; Covid-19; Education and Training Center; BDK Semarang

\begin{abstract}
ABSTRAK
Pandemi covid-19 melanda Indonesia, di sisi lain aktivitas dalam dunia pendidikan harus tetap berjalan. Tahun 2020 Balai Diklat Keagamaan (BDK) Semarang menerapkan Pelatihan Jarak Jauh (PJJ) Online. PJJ tersebut dilaksanakan untuk memberikan ruang untuk mendiklat pegawai Kemenag di daerah Yogyakarta dan Jawa Tengah. Tujuan penelitian ini adalah mengetahui konteks penyelenggaraan PJJ, input, proses dan produknya. Penelitian ini menggunakan jenis penelitian kualitatif deskriptif explanatif dengan pendekatan studi kasus evaluasi program. Metode dan teknik yang digunakan adalah wawancara, telaah dokumen dan observasi. Hasil penelitian dalam aspek input berupa
\end{abstract}

Fatimarur Rohmah, Abdul Wahid, Silviatul Hasanah 
sistem kerja yang diterapkan ialah sistem kerja secara bergantian, kurikulum yang diterapkan di PJJ sudah menyesuaikan dengan ketentuan dari Kemenag pusat, walaupun pada pelaksanaan teknis dilakukan inovasi. Pada proses PJJ, lembaga telah mengadakan bimtek untuk seluruh pegawai sehingga tidak ada kesenjangan dalam menggunakan teknologi, kuantitas peserta semakin banyak, namun terdapat kendala susah sinyal, dan peserta diberi penggantian pulsa. Sedangkan hasil yang dicapai pada pelaksanaan PJJ semua peserta lulus dengan nilai rata-rata 90. Rekomendasi untuk pihak lembaga agar pelaksanaan PJJ diprioritaskan untuk masuk dalam program kerja di tahun mendatang berupa kuantitas peserta dan kelas diperbanyak, serta fasilitas lembaga untuk melakukan pendidikan secara daring diperbagus

Kata Kunci: Evaluasi Daniel Stufflebeam; Pendidikan dan Pelatihan Jarak Jauh; Covid-19; BDK Semarang

\section{LATAR BELAKANG}

Pendidik dan Tenaga pendidik sangat berperan penting dalam upaya mewujudkan masyarakat yang cerdas. Namun terdapat kualifikasi, kompetensi, dan sertifikasi yang harus dipenuhi untuk menjadi guru, dosen dan tenaga kependidikan. Salah satunya ialah mengikuti pendidikan dan pelatihan di lembaga tertentu. Oleh karenanya untuk menuju pembangunan nasional, hadir sebuah subsistem yang memberikan peluang kepada masyarakat untuk melakukan suatu sistem pendidikan dan pelatihan nasional. Pegawai Negeri Sipil (PNS) mempunyai peranan yang menentukan keberhasilan penyelenggaraan negara dan pembangunan. ${ }^{1}$ Untuk menciptakan sumber daya manusia aparatur yang memiliki kompentensi tersebut diperlukan peningkatan mutu profesionalisme dan pengembangan wawasan PNS. Upaya yang telah ditempuh oleh Pemerintah dalam peningkatan mutu profesionalisme dan pengembangan wawasan PNS adalah melalui program Pendidikan dan Pelatihan (Diklat). ${ }^{2}$

${ }^{1}$ Jeane Marie Tulung, Evaluasi Program Pendidikan Dan Pelatihan Kepemimpinan Tingkat IV Di Balai Diklat Keagamaan Manad, (Journal "Acta Diurna" Vol. III. No.3 Tahun 2014), 2.

${ }^{2}$ Kementerian Agama, Ditjen Bimas Kristen Kementerian Agama RI, Himpunan Peraturan Perundang undangan, Bidang Pendidikan Dasar dan Menengah. Jakarta: Kemenag, 2011, 72 
Berdasarkan kebutuhan tersebut negara menyediakan sebuah lembaga yang khusus untuk melakukan pendidikan dan pelatihan (diklat). Salah satunya adalah lembaga Diklat yang berada di bawah naungan Kementrian Keagamaan. Eksistensi lembaga negara yang memiliki semboyan "Ikhlas Beramal" tersebut tentu memiliki peranan yang sangat penting. Keberadaannya menjadi jawaban atas permasalahan keagamaan dan negara, namun selain itu lembaga tersebut juga memiliki kewajiban membentuk masyarakat madani, adil, makmur, demokratis dan berakhlak mulia. Oleh karena itu, kementrian agama melakukan segala upaya untuk membentuk seorang PNS Kementerian Agama yang dapat menjadi contoh dan teladan bagi masyarakat, memiliki akhlak mulia, profesional, disiplin dan bertanggungjawab dalam menyelenggarakan tugas pemerintahan dan pembangunan. ${ }^{3}$

Tata Kerja Balai Diklat Keagamaan (BDK) tertuang dalam Peraturan Menteri Agama (PMA) No. 59 Tahun 2015 Pasal 2. Berisi tentang penjelasan organisasi, tugas pokok dan fungsi. Balai Diklat Keagamaan menyelenggarakan Pendidikan dan Pelatihan Tenaga Administrasi dan Tenaga Teknis Pendidikan dan Keagamaan. ${ }^{4}$ Dalam penelitian ini, penulis ingin berfokus melakukan penelitian di Balai Diklat Keagamaan (BDK) Semarang.

Berdasarkan pra riset yang sudah dilakukan, penulis menemukan adanya beberapa permasalahan. Apalagi tahun 2020 ini Indonesia tengah dilanda pandemi covid-19. Yang artinya lembaga harus melaksanakan pekerjaan sesuai protokal kesehatan. BDK telah memberikan putusan untuk melaksanakan program diklat dengan sistem online atau lebih sering disebut dengan Pelatihan Jarak Jauh (PJJ). Kalau tahun sebelumnya PJJ hanya dilaksanakan satu sampai dua kali saja, namun anggaran diklat telah dirubah dengan sistem PJJ sampai akhir tahun 2020. Diketahui BDK Semarang telah menyiapkan kursi pelatihan sebanyak 2.498 peserta dengan 44 kelas, namun sampai proposal ini ditulis diklat yang sudah terlaksana adalah sebanyak 18 kelas.

Sehubungan dengan adanya perubahan rencana pelaksanaan program diklat tersebut, penulis menemukan beberapa masalah dalam pelaksanaan PJJ. Dalam hal ini penulis menemukan proses input

\footnotetext{
3 Jeane Marie Tulung, Evaluasi Program Pendidikan Dan Pelatihan Kepemimpinan Tingkat IV Di Balai Diklat Keagamaan Manad, 2.

${ }^{4}$ Penjelasan Peraturan Menteri Agama (PMA) No. 59 Tahun 2015 Pasal 2), 3.
} 
(masukan) masih ada kekurangan, yakni koordinasi antar pegawai menjadi kurang efektif dan kinerjanya menjadi kurang maksimal. Kemudian kurikulum setiap angkatan diklat masih perlu pembaharuan. Selain itu dalam menghadapi era pandemi covid-19 sarana prasarana yang serba menggunakan teknologi juga menjadi kendala, karena masih kurang mendukung PJJ. Dalam hal process (proses) penulis menemukan adanya kendala dalam proses PJJ yang diharuskan menggunakan teknologi dan aplikasi berbasis video jarak jauh. Sedangkan peserta maupun pengajar ada yang masih kurang mampu menggunakan teknologi. Jadwal pelaksanaan diklat terkadang tidak sesuai dengan kurikulum yang ada, harus menyesuaikan kelonggaran instruktur atau pelatih. Hasil (produk) dari PJJ ini masih perlu pembenahan, karena pelaksanaan PJJ yang dilakukan belum cukup membuktikan secara sepenuhnya kemampuan yang dimiliki oleh PNS tersebut.

Dengan melihat berbagai permasalahan yang ada, menjadi dasar perlu diadakannya evaluasi pelatihan jarak jauh. Evaluasi ini menjadi salah satu program yang tidak bisa dipisahkan dalam serangkaian pelaksanaan diklat yang dilakukan secara rutin dan berkelanjutan. Oleh karena itu perlunya model evaluasi yang dapat memberikan informasi dan dapat dijadikan bahan pertimbangan dalam mengambil keputusan. Penulis akan memfokuskan masalah pada context, input, process dan output pelaksanaan pelatihan jarak jauh selama pandemic covid-19.

Mengingat beragamnya program pendidikan dan pelatihan yang dilaksanakan oleh BDK Semarang, maka penulis ingin membatasi permasalahan agar lebih terarah pada sistem context, input, process and output. Dengan merumuskan masalah sebagai berikut: (1) Bagaimana konteks pelaksanaan pelatihan jarak jauh selama pandemi covid-19 di Balai Diklat Keagamaan Semarang? (2) Bagaimana input (masukan) pelaksanaan pelatihan daring selama pandemi covid-19 di Balai Diklat Keagamaan Semarang? (3) Bagaimana process (proses) pelaksanaan pelatihan daring selama pandemi covid-19 di Balai Diklat Keagamaan Semarang? (4) Bagaimana output (keluaran/produk) pelaksanaan pelatihan jarak jauh selama pandemic covid-19 di Balai Diklat Keagamaan Semarang? 


\section{METODE PENELITIAN}

Metode penelitian yang digunakan oleh peneliti adalah kualitatif, dengan menggunakan studi kasus dan pendekatan evaluasi program. Penelitian dilakukan di Balai Diklat Keagamaan (BDK) Semarang dan dilaksanakan pada bulan Juli sampai dengan Agustus 2020. Pemilihan tempat ini didasarkan atas pertimbangan: (1) Balai Diklat Keagamaan (BDK) Semarang memiliki struktur dan kewenangan untuk melaksanakan diklat di wilayah Jawa Tengah dan Yogyakarta. (2) Balai Diklat Keagamaan (BDK) Semarang memiliki kewenangan untuk menyelenggarakan diklat khusus aparatur pemerintah.

Sumber data dalam penelitian adalah orang, objek, benda atau lembaga yang dapat memberikan informasi. Dalam penelitian ini informasi sumber data berasal dari sumber data primer dan sekunder. Data primer dalam penelitian ini yakni pegawai Balai Diklat Keagamaan Semarang dan peserta diklat. Sedangkan untuk data sekunder, terdiri dari dokumentasi dan foto- foto kegiatan yang kedudukannya mendukung dari data primer tadi. Fokus penelitian ini terdiri dari dua komponen, yakni subjek dan objek. Adapun untuk komponen subjek terdiri dari tiga, yakni: (1) Penyelenggara, (2) Pengajar atau Instruktur, (3) Peserta. Adapun objek penelitian ini meliputi (1) Aspek context (konteks). (2) Aspek input (masukan), (3) Aspek process (proses), (4) Aspek output (hasil). Adapun kerangka berfikir yang digunakan oleh peneliti adalah sebagai berikut: 


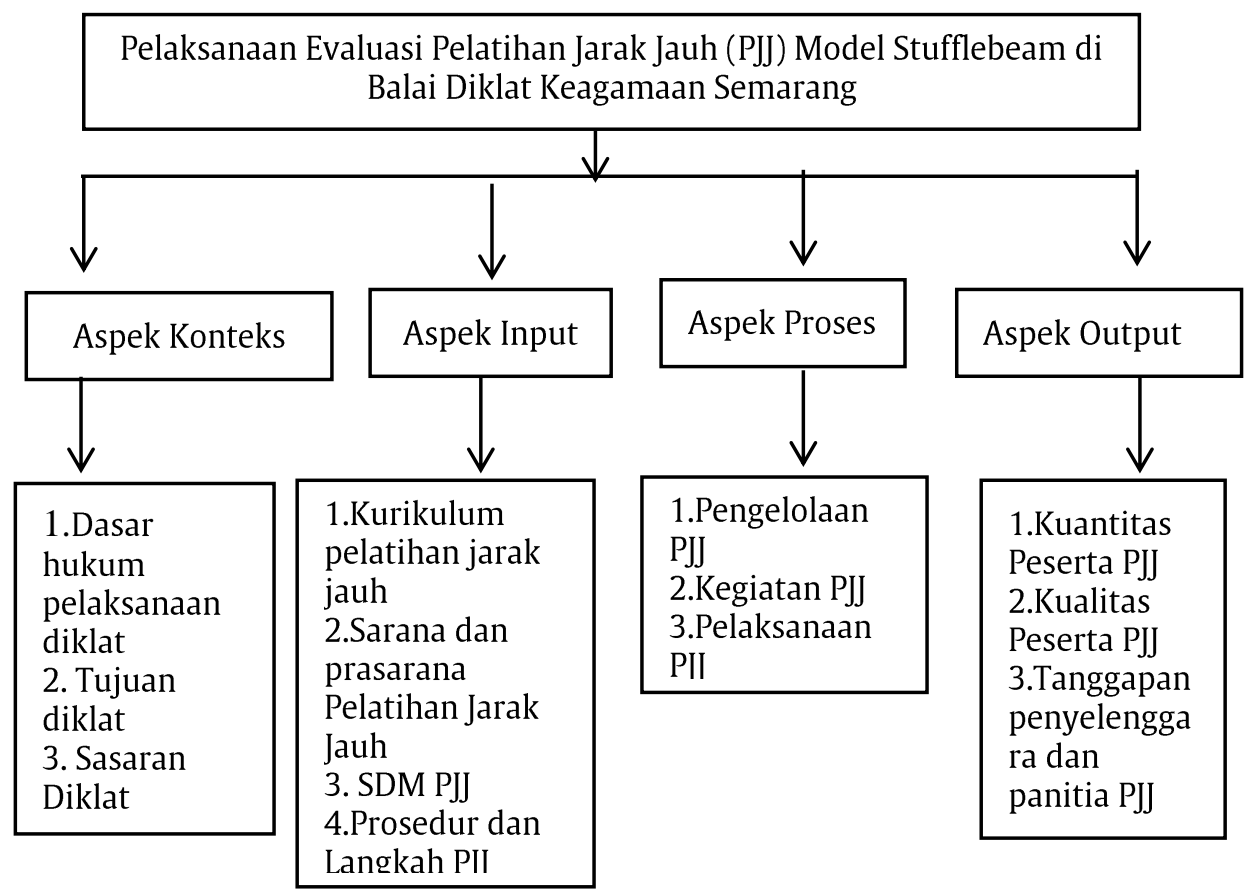

Gambar 1

Kerangka Berfikir Evaluasi Menurut Daniel F. Stufflebeam

\section{HASIL DAN PEMBAHASAN PENELITIAN}

Pelaksanaan Evaluasi dengan teori yang dicetuskan oleh Daniel F. Stufflebeam di Balai Diklat Keagamaan Semarang dapat dipaparkan sebagai berikut. Dalam penelitian peneliti fokus dalam empat aspek yakni Context, Input, Process and Output.

Aspek Context (Konteks) Pelaksanaan Pelatihan Jarak Jauh di BDK Semarang merujuk pada dasar hukum pelaksanaan diklat, tujuan, dan sasaran diklat. Berdasarkan data yang sudah didapatkan oleh peneliti evaluasi context (konteks) mengenai dasar hukum yang sudah dilaksanakan di Balai Diklat Keagamaan Semarang sudah memenuhi persyaratan sesuai dengan aturan dari pemerintah. Sedangkan menurut Suryosubroto, dalam kegiatan diklat, tujuan harus tertulis. ${ }^{5}$ Lebih lanjut menurut Madaus, "hasil evaluasi konteks harus memberikan dasar yang

${ }^{5}$ B. Suryosubroto, Manajemen Training: Buku Pegangan Kuliah untuk Mahasiswa Program Studi Manajemen Pendidikan, (Yogyakarta: Perpustakaan FIP UNY, 2004), 90. 
kuat untuk menyesuaikan tujuan dan prioritas yang ada dan menargetkan perubahan yang diperlukan". ${ }^{6}$

Evaluasi konteks pada tujuan dan sasaran pelaksanaan PJJ yaitu adanya kesenjangan kompetensi sumber daya manusia di wilayah Kemenag, antara yang mendapatkan pelatihan dan yang belum. BDK Semarang melaksanakan PJJ untuk memberikan ruang dan kapasitas yang lebih banyak kepada pegawai Kemenag untuk mengikuti pelatihan.

Kedua, pada aspek Input (Masukan) pelaksanaan PJJ di BDK Semarang terbagi menjadi empat bahasan, yakni terkait kurikum, sumber daya manusia, sarana prasarana dan prosedur pelaksanaan diklat. Terkait Kurikulum PJJ, Struktur kurikulum PJJ antara lain terdiri dari materi-materi pelatihan, berupa mata pelatihan inti dan penunjang, garis besar program pembelajaran, waktu pelatihan, kompetensi inti dan kompetensi dasar. Menurut Stufflebeam, dkk menyatakan bahwa evaluasi kurikulum dapat berupa: Fiskal dan Sumber Daya Manusia Buku Ajar dan kelengkapannya - Bahan Ajar - Perilaku Masuk Siswa Efektifitas Guru - Karakteristik Sekolah - Supervisi - Kondisi Program Pendidikan, dll. Masukan memberikan informasi tentang cara mencapai tujuan. $^{7}$

Kemudian pada bahasan mengenai latar belakang SDM PJJ baik pihak penyelenggara, pengajar dan peserta terdapat temuan- temuan yang peneliti lakukan. Sumber daya manusia yang berperan dalam pelaksanaan PJJ antara lain penyelenggara diklat, pengajar, dan peserta. Sesuai dengan pendapat Stufflebeam, dapatkah sumber daya yang ada dialokasikan, atau akankah sumber daya tambahan diperlukan? Sekali lagi, penekanannya adalah pada pengumpulan informasi yang akan digunakan oleh pengambil keputusan. ${ }^{8}$

Evaluasi input pada sumber daya manusia pihak widyaiswara atau pengajar yang melatih di PJJ masih minim, walaupun jumlah Widyaiswara di BDK Semarang ada 35 orang, namun ada beberapa pengajar yang IT-nya masih kurang. Namun pihak BDK Semarang telah melaksanakan BIMTEK guna menambah skill pegawai diklat dan

\footnotetext{
${ }^{6}$ Madaus, George F. et al.l, Evaluation Models (Viewpoints on Educational and Human Services Evaluation), (Boston: Kluwer-Nijhoff, 1986).. Hlm. 128.

7 Fernandes, H.J.X, Evaluation of Educational Program. (Jakarta: National Education Planning, Evaluation and Curriculum Development, 1984), 7.

${ }^{8}$ Roger Kaufman \& Susan Thomas, Evaluation Without Fear, (New York: A Division of Franklin Watss, 1980), 117.
} 
pengajar / widyaiswara. Untuk kepanitiaan PJJ sudah sesuai dengan aturan yang ditentukan oleh pihak balai, ada empat yakni ketua, admin LMS, Sekretaris dan anggota. Sedangkan untuk peserta PJJ sudah sesuai ketentuan, termasuk syarat, hak dan kewajiban sudah diterapkan oleh pihak BDK Semarang. Keuntungan lebihnya dalam pelaksanaan PJJ bisa menampung lebih banyak kelas, berbeda dengan diklat regular yang kelasnya terbatas. Menurut Stufflebeam menyatakan bahwa: evaluasi input berguna dalam mengidentifikasi apa yang sebenarnya akan diperlukan untuk memenuhi tujuan yang ditentukan dalam evaluasi konteks. Di sini keputusan berkisar pada masalah bagaimana menyusun program instruksional untuk memanfaatkan sumber daya sebaik-baiknya dalam memperoleh tujuan program yang diidentifikasi. ${ }^{9}$

Evaluasi aspek input dalam sarana dan prasarana di BDK Semarang sudah memenuhi kebutuhan peserta. Karena pandemi covid19 yang tengah berlangsung, oleh karenanya BDK Semarang memberikan pulsa sebagai sarana untuk bisa mengakses segala portal maya yang harus dimasuki peserta PJJ, tidak lain di blc.bdk.semarang.net. Namun kendala justru ditemukan pada pihak peserta yang kesulitan mendapatkan sinyal karena posisi tempat tinggal atau rumahnya jauh dari pusat kota.

Pembahasan terakhir proses input yakni terkait prosedur pelaksanaan PJJ. Prosedur merupakan salah satu rangkaian yang penting dalam pelaksanaan diklat, agar segala sesuatu terlaksana dengan baik. Prosedur didefinisikan sebagai serangkaian langkah yang tersusun secara sistematis berdasarkan urutan- urutan yang terperinci dan harus diikuti untuk dapat menyelesaikan permasalahan. ${ }^{10}$

Berdasarkan data hasil penelitian terdapat tiga alur sistem yang harus dijalankan, di BDK Semarang yakni persiapan, pelaksanaan dan evaluasi. Secara keseluruhan prosedur yang sudah diterapkan di BDK Semarang sudah tersusun secara rapi dan bisa dijalankan oleh semua pihak, baik peserta, pengajar maupun penyelenggara.

Ketiga, pada aspek process (proses) pelaksanaan pelatihan daring di BDK Semarang terbagi menjadi dua pembahasan, yakni pengelolaan

${ }^{9}$ Roger Kaufman \& Susan Thomas, Evaluation Without Fear, (New York: A Division of Franklin Watss, 1980), 117.

10 Lilis Puspitawati dan Sri Dewi Anggraini, Sistem Informasi Akuntansi, (Yogyakarta: Graha Ilmu, 2011), 28. 
dan kegiatan PJJ, yangmana masing- masing juga memiliki temuan tersendiri. Pertama, terkait pengelolaan PJJ terbagi menjadi empat temuan dan bahasan. Diantaranya mengenai jadwal PJJ. Menurut Kamil, tahapan penyusunan kegiatan pelatihan berkaitan dengan bahan belajar, metode dan teknik, serta media pembelajaran. Urutannya meliputi seluruh rangkaian aktivitas, dari pembukaan hingga penutupan. ${ }^{11}$

Berdasarkan data, PJJ dilaksanakan selama satu bulan dengan total keseluruhan 60 jam pelajaran (JP). Dalam sehari materi pembelajaran dilaksanakan pada pukul 13.00 wib dan berakhir sesuai kesepakatan kelas. Kemudian dilanjut pada malam hari. Dalam sehari penyelengara diklat membatasi maksimal 3 jp untuk PJJ. Pelaksanaan PJJ juga sudah sesuai dan tidak merugikan baik peserta maupun pengajar.

Berdasarkan kamus Besar Bahasa Indonesia absen merupakan kalimat verbal yang artinya tidak masuk atau tidak hadir, sedangkankan absensi artinya ketidakhadiran. Dimana artinya adalah daftar administrasi yang merekap terkait ketidakhadiran seorang pegawai, peserta, dll dalam suatu lembaga atau acara. Sedangkan menurut ahli, absensi merupakan kegiatan untuk membuktikan hadir atau tidak hadirnya seorang karyawan di suatu perusahaan. Absensi merupakan bentuk penerapan disiplin di perusahaan atau institusi. Pelaksanaan pengisian daftar hadir secara manual menjadi penghambat bagi organisasi dalam memantau kedisiplinan karyawan terkait ketepatan waktu kedatangan dan jam pulang karyawan setiap hari. Hal ini dapat membuat komitmen karyawan terhadap organisasi menjadi berkurang. Menurunnya, komitmen karyawan dalam bekerja dapat berdampak bagi motivasi dan kinerja karyawan. ${ }^{12}$

Menurut data hasil penelitian, evaluasi terhadap absensi peserta pada saat pelaksanaan PJJ terekam secara otomatis saat mereka login untuk membuka blc.bdksemarang.net. Daftar hadir absensi yang terisi sudah memenuhi kriteria untuk kelulusan peserta.

Penemuan dan bahasan selanjutnya mengenai penugasan saat PJJ. Pemberian tugas dapat memberikan tambahan pengalaman dan pengetahuan bagi siswa. Tugas biasanya dikerjakan secara individu dan

${ }^{11}$ Mustofa Kamil, Model Pendidikan dan Pelatihan, (Bandung: Alfabeta, 2010), 18.

12 Heriawanto, Analisis Faktor- Faktor yang mempengaruhi Motivasi Kerja Karyawan, ( Bogor: FPITB 2004), 97 
kelompok. Tugas yang hendaknya berkaitan erat dengan materi yang dipelajari, sesuai dengan kemampuan siswa, jelas prosedur pengerjaannya, dan batas waktu yang ditentukan untuk pengerjaan tugas tersebut. ${ }^{13}$ Menurut Syaiful Bahri Djamarah dan Aswan Zain, metode penugasan adalah metode penyajian bahan dengan memberikan tugas akhir tertentu agar siswa melakukan kegiatan belajar. ${ }^{14}$

Berdasarkan data penelitian yang ada, penugasan yang diberikan widyaiswara kepada peserta diklat antara lain peserta mengumpulkan tugas berupa upload video materi pembelajaran, diskusi perkelompok, dan upload video bahan ajar. Diberikan tenggat waktu 3-4 hari dan menggunakan sistem gugur, apabila tidak mengumpulkan otomatis tidak bisa melanjutkan ke sistem diklat.

Kemudian terkait dengan fasilitas peserta PJJ. Fasilitas merupakian sarana yang dapat memudahkan pelaksanaan fungsi. Fasilitas termasuk komponen individual dari penawaran yang mudah ditumbuhkan atau dikurangi tanpa mengubah kualitas dan model jasa. Selain itu, fasilitas dapat dikatakan sebagai alat yang membedakan program satu lembaga dengan lembaga lainnya. ${ }^{15}$

Berdasarkan data penelitian yang ada, fasilitas yang diberikan oleh pihak BDK Semarang saat melakukan PJJ berbeda dengan diklat yang pada umumnya dilakukan. Fasilitas yang diberikan adalah berupa pulsa, sebagai pengganti kuota yang sudah dikeluarkan oleh peserta saat sedang melaksanakan PJJ. Kemudian fasilitas lain selama PJJ berlangsung, BDK Semarang menyediakan alamat web tertentu untuk mengakses beberapa bahan ajar, cara pendaftaran dan sebagainya. Antara lain, Pendaftaran dan Pengelolaan PJJ secara online dapat dikirim melalui simdiklat.kemenag.go.id. Untuk masalah Registrasi online peserta membuka website https://bdksemarang.kemenag.go.id/halaman/eregistrasi.

Sistem Ujian Online bisa diakses di simudik.bdksemarang.net. Kemudian untuk mengirim atau mempunyai pertanyaan bisa ditanyakan melalui Email:bdk_semarang@kemenag.go.id. Peserta juga bisa 2013), 192

${ }^{13}$ Jamil Suprihatiningrum, Strategi Pembelajaran, (Yogyakarta: Ar Ruzz Media,

${ }^{14}$ Syaiful Bahri Djamarah dan Aswan Zain, Strategi Belajar Mengajar, (Jakarta: Rineke Cipta, 2006), 85.

${ }_{15}$ T. Hani Handoko, Dasar-dasar Manajemen Produksi dan Operasi, (BPFE: Yogyakarta, 2003), 101. 
mengakse

segala

informasi

melalui

website:

bdksemarang.kemenag.go.id. Sedangkan untuk akun sosial media, peserta bisa mengakses lewat Facebook: www.facebook.com/bdksemarang, Twitter: twitter.com/bdk_smg dan Instagram: www.instagram.com/bdksemarang. Peserta juga diberikan kemudian untuk melakukan pendaftaran sampai simulasi untuk mengumpulkan tugas di kanal youtube search channel: Balai Diklat Keagamaan Semarang.

Sedangkan apabila ada keresahan, terdapat Hotline Aduan: whatsapp/sms ke: 081-2272-1897. Penilaian Widyaiswara dan Panitia secara kuantitatif melalui Google Drive oleh panitia masing-masing. Penilaian terhadap WI dan penyelenggara secara kualitatif melalui: http://gg.gg/eva-diklat . Evaluasi Penyelenggaraan Pelatihan Jarak Jauh melalui: simudik.bdksemarang.net menu Surveys. Peserta mengupload SK Terakhir, Surat Tugas, Biodata dan Surat Pernyataan Kesanggupan pada minggu ketiga melalui: http://gg.gg/biodata-persyaratandjj . Peserta mengimplementasikan Rencana Tindak Lanjut dalam jangka waktu maksimal 30 hari setelah mengikuti Pelatihan Jarak Jauh dan mengunggah melalui laman djj.bdksemarang.net

Pembahasan kedua mengenai kegiatan PJJ. Pada temuan ini terdapat pembagian yakni terkait metode pembelajaran PJJ, materi yang digunakan dalam PJJ, proses monitoring dan evaluasi selama PJJ dan juga hambatan selama PJJ.

Metode adalah cara untuk mengimplementaskan rencana yang sudah disusun agar tujuan tercapai secara optimal. ${ }^{16}$ Metode digunakan dalam proses belajar mengajar sesuai dengan rencana yang telah ditetapkan. Menurut Abdurrahman Ginting, metode pembelajaran merupakan pola yang khas dengan memanfaatkan berbagai prinsip dasar pendidikan, atau berbagai teknik dan sumber daya terkait lainnya yang memandu proses pembelajaran para pembelajar. ${ }^{17}$ Berdasarkan data, metode pembelajaran yang dilakukan pihak BDK Semarang dilaksanakan melalui Video Conference, Tanya jawab, Pemberian tugas, Diskusi, Upload Video berupa upload bahan ajar atau bahan tayang.

${ }^{16}$ Wina Sanjaya, Strategi Pembelajaran Berorientasi Standar Proses Pendidikan (Jakarta: Kencana Prenada Media Group, 2008), 147.

${ }_{17}$ Abdurrahman Ginting, Essensi Praktis Belajar dan Pembelajaran (Bandung: Humaniora, 2008), 42. 
Materi pembelajaran atau materi ajar adalah salah satu sumber belajar yang berisi pesan berupa konsep, prinsip, definisi, gugus isi, data maupun fakta, proses, nilai, kemampuan dan keterampilan. Materi yang dikembangkan hendaknya mengacu pada kurikulum atau silabus yang disesuaikan dengan kebutuhan dan lingkungan siswa. ${ }^{18}$

Berdasarkan data hasil penelitian, diketahui bahwa materi pembelajaran dalam proses pelaksanaan PJJ terbagi menjadi dua kategori, yakni materi inti dan materi penunjang. Kedua materi bisa terlaksana sesuai dengan ketentuan, namun tidak semua jenis mata pelatihan bisa di PJJ kan, karena ada PJJ hanya dijalankan pada materi kompetensi umum, sedangkan untuk kompetensi professional tidak bisa di PJJ-kan.

Menurut Hasibuan, proses belajar mengajar harus dievaluasi dengan ujian untuk mengetahui sasaran pengembangan tercapai atau tidak. ${ }^{19}$ Terdapat dua bentuk evaluasi dalam pendidikan dan pelatihan, yaitu pertama, evaluasi akhir, tahap ini dilakukan untuk mengetahui keberhasilan belajar. Kegiatan ini diharapkan mengetahui daya serap dan penerimaan siswa terhadap berbagai materi yang disampaikan. ${ }^{20}$ Dengan demikian, penyelenggara dapat mengambil langkah tindak lanjut yang relevan. Kedua, evaluasi program pelatihan, yang merupakan kegiatan awal untuk menilai seluruh kegiatan pelatihan dari awal sampai akhir. Hasilnya dapat menjadi masukan bagi pengembangan pelatihan berikutnya.

Berdasarkan data hasil penelitian, evaluasi yang ada di BDK Semarang sudah sesuai dengan ketentuan. Ada 4 macam evaluasi yakni, evaluasi terhadap peserta, evaluasi terhadap pengajar, evaluasi terhadap penyelenggaraan diklat dan evaluasi program yang selalu rutin dilaksanakan oleh pihak BDK Semarang setiap kali menyelenggarakan diklat.

Hambatan adalah sebuah halangan, rintangan atau suatu keadaan yang tidak dikehendaki atau disukai kehadirannya, menghambat perkembangan seseorang, menimbulkan kesulitan baik bagi diri sendiri

18 Darwin Syah, Perencanaan Sistem Pengajaran Pendidikan Agama Islam, (Jakarta: Gaung Persada Press, 2007), 69.

19 Malayu S.P Hasibuan, Manajemen Sumber Daya Manusia (Edisi Revisi). (Jakarta: Bumi Aksara, 2001), 75.

${ }^{20}$ Mustofa Kamil, Model Pendidikan dan Pelatihan, (Bandung: Alfabeta, 2010), 19. 
maupun orang lain dan ingin atau perlu dihilangkan. ${ }^{21}$ Berdasarkan data hasil penelitian dapat disimpulkan bahwasanya hambatan yang ada dalam pelaksanaan PJJ diantaranya adalah belum ada pembaharuan server saat dilakukan wawancara dengan pihak BDK Semarang, kendala sinyal di peserta. Dua hal itu menjadi kendala besar yang sampai pada penulisan skripsi ini masih dalam proses untuk menemukan solusinya.

Pembahasan terakhir mengenai aspek product (produk/ keluaran) pelaksanaan PJJ di BDK Semarang. Pada bahasan dan temuan ii terbagi menjadi dua bagian, yakni terkait kuantitas dan kualitas peserta PJJ dan tanggapan peserta mengenai program PJJ.

Menurut Atmodiwiro, keberhasilan program pelatihan dapat diketahui dari beberapa hal, yaitu (1) reaksi peserta, (2) hasil pembelajaran, dan (3) hasil pelatihan serta dalam pekerjaan. ${ }^{22}$ Sedangkan menurut Kamil, keluaran yang dievaluasi meliputi kualitas dan kuantitas peserta didik setelah mengalami proses pembelajaran. ${ }^{23}$ Kuantitas merupakan jumlah peserta didik yang berhasil menyelesaikan proses pembelajaran, sedangkan kualitas merupakan derajat perubahan tingkah laku peserta didik secara kognitif, afektif, dan psikomotorik.

Berdasarkan data, hasil pre test menunjukkan angka rata- rata 68 , 69. Sedangkan untuk post test menunjukkan angka rata-rata 86, 87. Dapat disimpulkan bahwasanya kemampuan peserta diklat meningkat setelah mengikuti Pelatihan Jarak Jauh. Namun, hasil nilai pre teset dan post test tidak dimasukkan dalam rekapitulasi penentuan nilai akhir PJJ, hanya sebatas untuk mengukur kemampuan peserta. Sedangkan untuk nilai hasil PJJ, didapatkan sejumlah 70 peserta telah mengikuti pelatihan dengan predikat 29 peserta "sangat baik" dan 41 peserta dengan predikat "baik". Untuk rata- rata nilai hasil yang diperoleh dalam satu angkatan kelas ini adalah 90, 96. Untuk penentuan nilai akhir merupakan nilai akumulasi dari Nilai Hasil dan nilai Rencana Tindak Lanjut (RTL). Sejumlah 70 peserta telah "Lulus" dengan predikat 20 peserta "sangat kompeten" dan 50 peserta "kompeten". Dan nilai rata- rata yang dicapai adalah 90, 60 .

21 Poerwadarminta, W.J.S, Kamus Umum Bahasa Indonesia. (Jakarta: Balai Pustaka), 99

${ }^{22}$ Mustofa Kamil, Model Pendidikan dan Pelatihan, (Bandung: Alfabeta, 2010), 64.

61.

${ }^{23}$ Mustofa Kamil, Model Pendidikan dan Pelatihan, (Bandung: Alfabeta, 2010),

Fatimarur Rohmah, Abdul Wahid, Silviatul Hasanah 
Dapat disimpulkan kuantitas yang mengikuti PJJ sudah sesuai yang diharapkan dan tingkat kelulusan peserta sudah mencapai 98\%. Ini artinya PJJ yang sudah dilaksanakan sudah sesuai dengan harapan dan tujuan awal diklat dilaksanakan.

Berdasarkan data yang telah didapatkan oleh peneliti, evaluasi Pelatihan Jarak Jauh yang dilaksanakan di BDK Semarang dibagi menjadi empat jenis, yakni evaluasi terhadap peserta, pengajar, penyelenggara dan evaluasi program. Evaluasi terhadap peserta dilakukan dengan ujian tertulis dan ujian komprehensif (ujian lisan), kemudai beberapa tugas untuk mengupload video bahan ajar. Sedangkan evaluasi terhadap isntruktur dan penyelenggara (fasilitas) dilakukan dengan mengisi kuesioner yang telah disediakan. Jadi dapat disimpulkan bahwa proses evaluasi yang dilakukan dapat dikatakan sudah baik karena dilakukan secara menyeluruh.

\section{SIMPULAN}

Berdasarkan hasil penelitian, pembahasan dan analisis data yang di lakukan oleh peneliti pada penelitian yang berjudul "Evaluasi Pelaksanaan Pendidikan Dan Pelatihan Jarak Jauh Selama Pandemi Covid19 (Studi Kasus Balai Diklat Keagamaan Semarang)", maka dapat ditarik kesimpulan sebagai berikut. Context pelaksanaan PJJ selama pandemi covid-19 di BDK Semarang didasarkan pada peraturan yang dibuat oleh pemerintah. Diantaranya yakni Mulai dari peraturan UU No. 20 Tahun 2003 Tentang Sisdiknas, UU No. 5 Tahun 2014 tentang Aparatur Sipil Negara, PP terkait PNS, PMK, PMA No. 75 dan 59 Tahun 2015. Tujuan dan sasaran diklat juga sudah sangat jelas. Namun pada sasaran, terdapat kesenjangan kompetensi SDM di wilayah Kemenag, antara yang mendapatkan pelatihan dan yang belum, olehkarenanya BDK Semarang melaksanakan PJJ untuk memberikan ruang dan kapasitas yang lebih banyak kepada pegawai Kemenag untuk mengikuti pelatihan.

Input pelaksanaan PJJ selama pandemi covid-19 di BDK Semarang diantaranya terdapat tiga sub bahasan. Pertama, dapat disimpulkan evaluasi untuk aspek kurikulum PJJ sudah relevan dengan kebutuhan dan tujuan diklat. Namun, bahan-bahan materi penunjang perlu direncanakan kembali berupa penambahan materi yang sifatnya mengarah ke penambahan skill penggunaan teknologi. Karena pandemi covid-19 menuntut semua lini untuk bisa menggunakan teknologi 
dengan cerdas. Kedua, kepanitiaan PJJ sudah sesuai dengan aturan yang ditentukan oleh pihak balai, ada empat yakni ketua, admin LMS, Sekretaris dan anggota. Keuntungan lebihnya dalam pelaksanaan PJJ bisa menampung lebih banyak kelas, berbeda dengan diklat regular yang kelasnya terbatas. Ketiga, sarana dan prasarana di BDK Semarang sudah memenuhi kebutuhan peserta. Karena pandemi covid-19 yang tengah berlangsung, oleh karenanya BDK Semarang memberikan pulsa sebagai sarana untuk bisa mengakses laman yang harus di akses yakni blc.bdk.semarang.net. Namun kendala justru ditemukan pada pihak peserta yang kesulitan mendapatkan sinyal karena posisi tempat tinggal atau rumahnya jauh dari pusat kota.

Process pelaksanaan PJJ selama pandemi covid-19 BDK Semarang terdapat dua sub besar, yakni pengelolaan dan kegiatan PJJ. Pertama, proses pengelolaan terdiri dari proses pelaksanaan PJJ terdapat tiga alur sistem yang dijalankan, yakni persiapan, pelaksanaan dan evaluasi. Secara keseluruhan prosedur yang sudah diterapkan di BDK Semarang sudah tersusun secara rapi dan bisa dijalankan oleh semua pihak, baik peserta, pengajar maupun penyelenggara. PJJ dilaksanakan selama satu bulan dengan total keseluruhan 60 JP. Pelaksanaan PJJ sudah sesuai dan tidak merugikan baik peserta maupun pengajar. Sedangkan absensi peserta pada saat pelaksanaan PJJ terekam secara otomatis saat mereka login untuk membuka blc.bdksemarang.net. Penugasan yang diberikan widyaiswara kepada peserta diklat antara lain peserta mengumpulkan tugas berupa upload video materi pembelajaran, diskusi perkelompok, dan upload video bahan ajar. Diberikan tenggat waktu 3-4 hari dan menggunakan sistem gugur, apabila tidak mengumpulkan otomatis tidak bisa melanjutkan ke sistem diklat. Fasilitas yang diberikan adalah pulsa. Selain itu, mereka menyediakan alamat web blc.bdksemarang.net untuk pelaksanaan PJJ. Kedua, kegiatan yang dilakukan meliputi, metode pembelajaran yang dilakukan oleh pihak BDK Semarang yakni pembelajaran dilaksanakan melalui Video Conference, Tanya jawab, Pemberian tugas, Diskusi, Upload Video berupa upload bahan ajar atau bahan tayang. Sedangkan materi pembelajaran dalam proses pelaksanaan PJJ terbagi menjadi dua kategori, yakni materi inti dan materi penunjang. Kedua materi bisa terlaksana sesuai dengan ketentuan, namun tidak semua jenis mata pelatihan bisa di PJJ kan, karena PJJ hanya dijalankan pada materi kompetensi umum, sedangkan 
untuk kompetensi professional tidak bisa. Selain itu, ada proses monitoring dan evaluasi selama PJJ berlangsung. Ada 4 macam evaluasi yakni, evaluasi terhadap peserta, evaluasi terhadap pengajar, evaluasi terhadap penyelenggaraan diklat dan evaluasi program yang selalu rutin dilaksanakan oleh pihak BDK Semarang setiap kali menyelenggarakan diklat. Hambatan yang ditemui adalah kendala sinyal di peserta.

Product pelaksanaan PJJ selama pandemi covid-19 di BDK Semarang Pada aspek produk, dua hal besra yang dapat disimpulkan yakni mengenai kuantitas dan kualitas peserta dan juga tanggapan dan evaluasi peserta terhadap penyelenggaraan PJJ. Penentuan nilai akhir merupakan nilai akumulasi dari Nilai Hasil dan nilai RTL. Sejumlah 70 peserta telah "Lulus" dengan predikat 20 peserta "sangat kompeten" dan 50 peserta "kompeten". Dan nilai rata- rata yang dicapai adalah 90, 60. Dapat disimpulkan kuantitas yang mengikuti PJJ sudah sesuai yang diharapkan dan tingkat kelulusan peserta sudah mencapai 98\%. Ini artinya PJJ yang sudah dilaksanakan sudah sesuai dengan harapan dan tujuan awal diklat dilaksanakan. Sedangkan untuk tanggapan mengenai pelaksanaan PJJ baik dari pengajar, panitia penyelenggara dan peserta menginginkan pelaksanaan PJJ untuk diperbanyak dan masuk dalam prioritas dalam program kerja diklat tahun depan, mengingat pandemi covid-19 masih belum bisa disembuhkan secara total.

\section{REKOMENDASI}

Demi terwujudnya pelayanan lembaga BDK Semarang yang semakin terdepan, maka penulis memberikan saran berupa pelaksanaan PJJ harusnya tidak hanya dimaksimalkan pada saat pandemi covid-19 saja, namun pada tahun- tahun selanjutnya harus tetap berjalan, karena kuantitas PNS yang membutuhkan pelatihan di luar sana juga masih banyak. Harapannya antara diklat regular dan PJJ seimbang. Kemudian kemampuan teknologi baik dari pegawai, widyaiswara dan penyelenggara harus ditingkatkan. 


\section{DAFTAR PUSTAKA}

Ditjen Bimas Kristen Kementerian Agama RI. (2011). Himpunan

Peraturan Perundang Undangan, Bidang Pendidikan Dasar dan Menengah.

Djamarah, S. B., \& Zain, A. (2006). Strategi Belajar Mengajar. Rineke Cipta. Fernandes, H. J. X. (1984). Evaluation of Educational Program. National Educational and Curriculum Development.

Ginting, A. (2008). Essensi Praktis Belajar dan Pembelajaran. Humaniora. Handoko, T. H. (2003). Dasar-Dasar Manajemen Produksi dan Operasi. BPFE.

Hasibuan, M. S. P. (2010). Manajemen Sumber Daya Manusia. Bumi Aksara.

http://repository.pelitabangsa.ac.id/xmlui/handle/123456789/1720

Heriawanto. (2004). Analisis Faktor- Faktor yang Mempengaruhi Motivasi Kerja Karyawan. FPITB.

Kamil, M. (2010). Model Pendidikan dan Pelatihan. Alfabeta. http://opac.ut.ac.id/detail-opac?id=30759

Kaufman, R. A., \& Thomas, S. (1980). Evaluation Without Fear.

Menteri Agama RI. (2015). Peraturan Menteri Agama Republik Indonesia Nomor 59 Tahun 2015 Tentang Organisasi dan Tata Kerja Balai

Pendidikan dan Pelatihan Keagamaan.pdf(p. 9).

Poerwadarminta, W. J. S. (n.d.). Kamus Umum Bahasa Indonesia. Balai Pustaka.

Puspitawati, L., \& Anggraini, S. D. (2011). Sistem Informasi Akuntansi. Graha Ilmu.

Sanjaya, W. (2008). Strategi Pembelajaran Berorientasi Standar Proses Pendidikan. Media Group.

Stufflebeam, D. L., Madaus, G. F., \& Kellaghan, T. (1986). Evaluation Models: Viewpoints On Educational and Human Services Evaluation (First). Kluwer Academic Publisher.

Suprihatiningrum, J. (2013). Strategi Pembelajaran. Ar Ruzz Media. Suryosubroto, B. (2004). Manajemen Training: Buku Pegangan Kuliah

Untuk Mahasiswa Program Studi Manajemen Pendidikan.

Perpustakaan FIP UNY.

Syah, D. (2007). Perencanaan Sistem Pengajaran Pendidikan Agama Islam. Gaung Persada Press.

Tulung, J. M. (2014). Evaluasi Program Diklat Kepemimpinan Tkt IV di Balai Diklat Keagamaan Manado. Acta Diurna, III(3), 1-16. 